\title{
Study of the Economic Valuation of Gemah Beach Tourism During the Covid-19 Pandemic in Tulungagung Regency, East Java
}

\author{
Vivi Tiara Mandela*, Sudrajat Sudrajat Rika Harini \\ Geography Study Program, Faculty of Geography, Gadjah Mada University, Yogyakarta, Indonesia
}

\begin{abstract}
The engulfing COVID-19 pandemic in various regions affected various sectors, one of which was the Indonesian tourism sector. The policy of social restrictions and travel restrictions led to a decrease in tourists at almost all tourist attractions. The purpose of this study is to identify the type of economic value generated by Gemah Beach tourism objects during the Covid-19 pandemic and evaluate the total economic value generated by Gemah Beach tourism objects during the Covid-19 pandemic. This research method uses a survey method by taking a sample of a number of tourists, business people, managers of Gemah Beach tourism objects. The type of data collected consists of primary data and secondary data. The economic valuation method is used to calculate the total economic value of the Gemah Beach tourism object obtained from direct use value, indirect use value, preferred use value, existence value, and bequest value. Data analysis used descriptive quantitative. The results of the study still found various types of economic activities carried out by business actors at the Gemah Beach tourism object during the COVID-19 pandemic, despite the government's social and economic restrictions. Meanwhile, based on the results of the economic valuation of the Gemah Beach tourism object during the COVID-19 pandemic, a total economic value of IDR 28,131,949,529 was obtained. The total economic value, according to tourism managers, is lower than before the COVID-19 pandemic due to activity restrictions and a decrease in the number of visitors. Optimizing the economic and natural potential of the Gemah Beach tourist attraction with the fulfillment of facilities and infrastructure in accordance with the COVID-19 health protocol can be used as a strategy in dealing with the COVID-19 pandemic so that the tourism industry can continue to grow.
\end{abstract}

\section{Introduction}

Tulungagung Regency is geographically a regency that is directly facing the Indian Ocean and has the potential of the region and nature that supports it to be developed. Tulungagung Regency has a coastline of $54 \mathrm{~km}$, extending from Besuki District to Pucanglaban District, The magnitude of the potential possessed by Tulungagung Regency is a driving force for increasing tourist visits every year. This is evidenced by the increasing number of foreign and domestic tourist arrivals in Tulungagung Regency in 2014-2018, Based on data from the Culture and Tourism Office of Tulungagung Regency in 2019, the number of visitors to Gemah Beach reached 114,875 tourists. However, since the COVID-19 pandemic emerged in early 2020, the tourism industry in Tulungagung Regency has experienced a decrease in the number of visitors [1]. This is due to the policy of travel restrictions and restrictions. Even with the existence of quarantine policies to suppress the spread of the virus, it has become an extreme vulnerability and challenge for the tourism industry itself [2].

Limited mobility during the pandemic caused a decrease in tourist visits to Gemah Beach in Tulungagung Regency. The economic value of utilizing Gemah Beach tourism as a tourist attraction is often neglected; thus, data on quantitative economic value is still lacking or even non-existent. In addition, the ignorance of some parties to the value of natural resources and the environment, especially at the Gemah Beach tourist attraction, will lead to disproportionate policy decisions. Systems theory and crisis management argue that crises need to be tackled collectively. Therefore the government needs policies and strategies for tourism destinations as tourism in the future [3]. Especially in the COVID-19 pandemic situation where restrictions on social and economic activities are government policies that must be obeyed. In fact, during the COVID-19 pandemic, economic activity in tourist areas had stopped when the government imposed a ban on activities outside the home. As a result, tourism activities have stopped because of the closure of tourist attractions and prohibiting tourist visits.

The COVID-19 pandemic situation where restrictions on social and economic activities are government policies must be adhered to. In fact, during the COVID-19 pandemic, economic activity in tourist areas had stopped when the government imposed a ban on activities outside the home. As a result, tourism activities have stopped due to the closure of tourist attractions and prohibiting tourist visits. The decrease in the number of visitors economically will have an impact on economic activity and a decrease in the resulting economic value. Therefore, to see the extent of changes in economic value that occurred due to the Covid-19 pandemic, economic valuation is very necessary. An economic valuation can be an important instrument in

\footnotetext{
*Corresponding author:vivi.tiara.mandela@mail.ugm.ac.id
} 
increasing public appreciation and awareness of goods and services produced by natural resources and the environment [4]. This means, economic valuation is also an effort to provide a quantitative value for goods and services produced by natural resources and the environment at market value and non-market value [5]. Economic valuation is essential [6] because environmental resources play an important role in human well-being as well as to control and prevent damage at tourist sites. Based on this, this research was conducted with the aim of identifying the types of

$$
\begin{gathered}
Y=a+\beta_{1} X_{1}+\beta_{2} X_{2}+\beta_{3} X_{3}+\beta_{4} X_{4} \\
+\beta_{5} X_{5}+e i
\end{gathered}
$$

economic value sharing generated by Gemah Beach tourism objects and evaluating the total economic value generated by Gemah Beach tourism objects during the Covid-19 pandemic.

\section{Methodology}

This research was conducted at the Gemah Beach tourist attraction, Tulung Agung Regency. The population in this study were tourists, business actors and tourist managers in the Gemah Beach area. The number of samples for tourists were 93 tourists who were taken by accidental sampling and for business actors were taken by census, while for managers were taken by purposive sampling. There are two types of data used in this study including primary data and secondary data. Primary data is data obtained from observations, interviews with respondents and indept interviews. Secondary data is data obtained by researchers indirectly through intermediary media. Secondary data in this study were obtained from books, journals, previous research, online news and official documents from the government or tourism object managers.

The economic valuation method used in this study is to calculate the total economic value of the tourism object including direct use value, indirect use value, optional use value, existence value, and bequest value of Gemah Beach tourism object in Tulungagung Regency [7]. The total economic value (TEV) of the Gemah Beach tourist attraction is the total sum of all the benefits from utilization at that location, with the following formula :

$$
T E V=(D U V+I U V+O V)+(X V+B V)
$$$$
\text { Details : }
$$

DUV = Direct Use Value

IUV $=$ Indirect Use Value

$\mathrm{OV} \quad=$ Option Value

$\mathrm{XV} \quad=$ Existence Value

$\mathrm{BV}=$ Bequest Value

Furthermore, to determine the value of each benefit value, the following analytical methods are used :

\subsection{Travel Cost Method (TCM)}

The travel cost method is a function of tourism demand based on the frequency of visits as the dependent variable described in a linear equation and the independent variable as the explanatory variable. Factors that influence tourism demand from Gemah Beach attractions are identified using the Individual Travel Cost Method (ITCM) which is part of the Travel Cost Method (TCM). Multiple linear regression analysis [8] was used in this study to determine the factors that influence the demand for visits to the Gemah Beach tourist attraction, statistically formulated as follows : Details :

$$
\begin{array}{ll}
\mathrm{Y} & =\text { Tourism visit request } \\
\mathrm{X}_{1} & =\text { Total cost of travel to Gemah Beach tourist } \\
& \text { attraction (Rupiah/person) } \\
\mathrm{X}_{2} & =\text { Distance from home to tourist attraction } \\
\mathrm{X}_{3} & =\text { Total income of respondents } \\
\mathrm{X}_{4} & =\text { Respondents's Education Level } \\
\mathrm{X}_{5} & =\text { Respondents Age } \\
\beta_{1}-\beta_{5} & =\text { Regression coefficient for factor } \mathrm{X}_{1}-\mathrm{X}_{3} \\
\mathrm{ei} & =\text { Error term }
\end{array}
$$

Furthermore, to calculate the economic value of the Gemah Beach tourist attraction uses the lower limit formulation, i.e. the lowest cost incurred by tourists, and the upper limit is the highest cost that tourists spend when travelling at the Gemah Beach tourist attraction. Therefore the integral equation for consumer surplus is as follows:

$$
C S=\int_{p 0}^{p 1} f(P x) d P
$$

\subsection{Contingent Valuation Method (CVM)}

The CVM method uses WTP (Willingnes to Pay) as a parameter for calculating the total benefit. Similar to the consumer surplus estimation approach, in calculating the WTP of tourists use the contingency assessment method [9] it can be done by using the average tourist willingness to pay for environmental services and multiplied by the total tourists in a certain year, the formula for calculating the WTP of tourists is as follows

$$
T B=W T P i x P t
$$

TB is the total benefit; WTPi is the individual WTP value; $\mathrm{Pt}$ is the total population/number of tourists in the $t$ year relevant to the analysis or the number of tourists in the one year of the covid-19 pandemic 

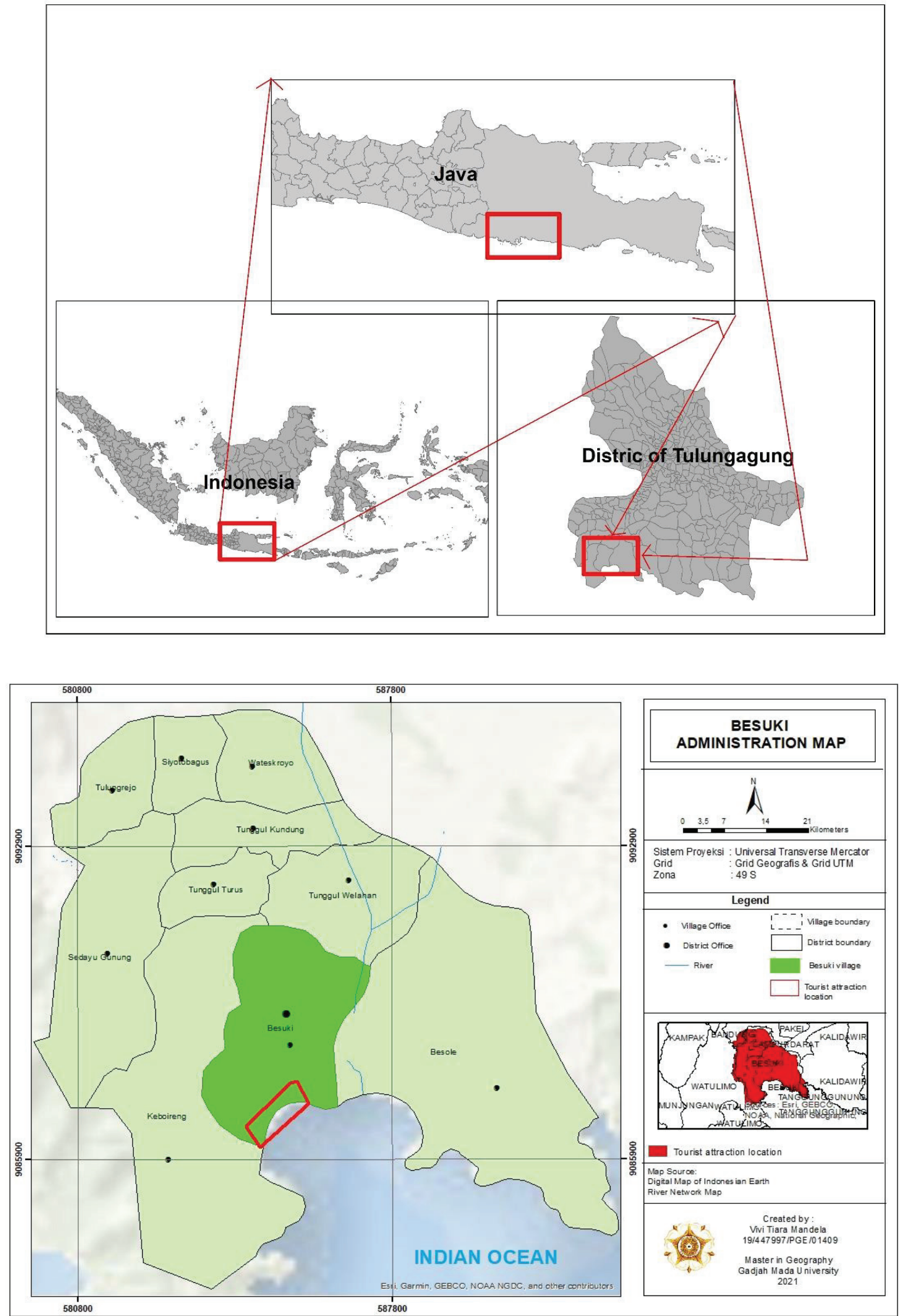

Fig. 1. The research location at Gemah Beach Tourism Object Tulungagung Regency, East Java 


\section{Result and Discussion}

\subsection{Types of Economic Benefit Value of Gemah Beach Tourism Object}

Gemah Beach tourism object is one of the mainstay tourist attractions in Tulungagung Regency, the restoration of this tourist attraction during the Pandemic period is a priority for the current Tulungagung Regency government (Tulungagung Regency Tourism Office, 2021). The existence of the Gemah Beach tourist attraction plays an important role in improving the local community's economy. Gemah Beach attractions are socially, economically and environmentally beneficial. The economic benefits of these attractions can be calculated through the economic valuation method. The economic valuation method requires a process of identifying the economic values that exist in the tourist attraction. Identification of the economic value of the Gemah Beach tourism object refers to the use value and non-use value of its use. The economic value identified by Gemah Beach tourism object can be seen in Table 1 . Below.

Table .1 The economic value identified by Gemah Beach tourism object

\begin{tabular}{|c|c|c|}
\hline \multicolumn{2}{|c|}{$\begin{array}{l}\text { Type of Economic } \\
\text { Value }\end{array}$} & Benefits \\
\hline \multirow[t]{3}{*}{$\begin{array}{l}\text { Use } \\
\text { value }\end{array}$} & $\begin{array}{l}\text { Direct use } \\
\text { value }\end{array}$ & Tourist attractions \\
\hline & $\begin{array}{l}\text { Indirect use } \\
\text { value }\end{array}$ & $\begin{array}{l}\text { The economic benefits of the } \\
\text { surrounding community include } \\
\text { traders, employees or managers, } \\
\text { retribution and parking. }\end{array}$ \\
\hline & $\begin{array}{l}\text { Option use } \\
\text { value }\end{array}$ & $\begin{array}{l}\text { Means of environmental } \\
\text { preservation and conservation }\end{array}$ \\
\hline \multirow[t]{2}{*}{$\begin{array}{l}\text { Non- } \\
\text { use } \\
\text { value }\end{array}$} & $\begin{array}{l}\text { Existence } \\
\text { value }\end{array}$ & $\begin{array}{l}\text { The existence of Gemah Beach } \\
\text { tourist attraction as a } \\
\text { promotional medium for tourism } \\
\text { objects in Tulungagung } \\
\text { Regency }\end{array}$ \\
\hline & Bequest value & $\begin{array}{l}\text { The magnificence and } \\
\text { cleanliness of the Gemah Beach } \\
\text { tourist attraction costs money so } \\
\text { that its sustainability can be } \\
\text { enjoyed by future generations }\end{array}$ \\
\hline
\end{tabular}

Source: Data Processing Results, 2021

The total economic value of Gemah Beach tourism object is calculated from direct use value, indirect use value, optional use value, existence value, and bequest value. The direct use value of the Gemah Beach tourist attraction is the value of the direct benefits received by tourists. The direct use value of tourism objects according to Fauzi (2014) is one of the economic values related to tourism activities to fulfill recreational needs. In Figure 2 it appears that the number of tourist visits from year to year is relatively increasing, but from 2020 to 2021 the number has decreased due to the covid-19 pandemic.

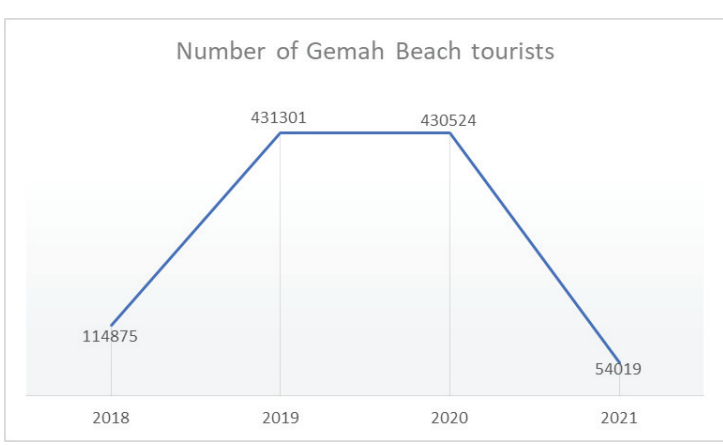

Fig. 2. Graph of the Number of Tourists at Gemah Beach Tourism Object

The indirect use value of the Gemah Beach tourism object is an economic benefit that is received and felt by the surrounding community and other parties. The results of the research are some of the economic benefits felt by the community in activities in the field of trade and services. In addition, the contribution of the community around the tourism object as a tourism object manager, as a parking guard, ticket counter guard and cleanliness is an economic benefit from the indirect use value of Gemah Beach tourism object. Another economic benefit which is an indirect benefit value is retribution income from tickets and tourist parking.

The option use value of the Gemah Beach tourist attraction is the value of economic benefits related to the preservation of the natural environment and conservation. Furthermore, the Gemah Beach tourist attraction is also used as a place to carry out health activities such as joint exercises on Sunday mornings with fresh air. Meanwhile, the value of the existence of the Gemah Beach tourist attraction is the value of the economic benefits associated with the existence of a tourist attraction in that location. Then, the value of the economic benefits of the existence of the Gemah Beach tourist attraction is as a promotional media for the surrounding tourist objectsthen the benefits of the existence of the Gemah Beach tourist attraction can be a promotional media for others such as Bayem Beach tourism, Klatak Beach, Niama Beach, Popoh Beach and JLS (South Cross Road).

The bequest value of the Gemah Beach tourist attraction is the value of the benefits of preserving the magnificence and cleanliness that is enjoyed by the next generation. The bequest value is calculated to find out how much value will be given for the sake of preserving the magnificence and cleanliness of the Gemah Beach tourist attraction.

\subsection{Valuation of Economic Value of Gemah Beach Tourism Object}

In this study, the calculation of the direct use value of the Gemah Beach tourism object used the travel cost method. The travel costs method is calculated by the amount of costs incurred by each tourist to visit the Gemah Beach tourist attraction. These costs consist of transportation costs, accommodation, consumption, 
souvenirs, entrance tickets, parking, and rides issued by tourists while at the Gemah Beach tourist attraction.

Table 2. Coefficients

\begin{tabular}{|c|c|c|c|c|c|}
\hline \multicolumn{6}{|c|}{ Coefficients $^{\mathrm{a}}$} \\
\hline \multirow{2}{*}{ Model } & \multicolumn{2}{|c|}{$\begin{array}{l}\text { Unstandardized } \\
\text { Coefficients }\end{array}$} & \multirow{2}{*}{$\begin{array}{c}\begin{array}{c}\text { Standardized } \\
\text { Coefficients }\end{array} \\
\text { Beta }\end{array}$} & \multirow{2}{*}{$\mathrm{t}$} & \multirow{2}{*}{ Sig. } \\
\hline & B & $\begin{array}{l}\text { Std. } \\
\text { Error }\end{array}$ & & & \\
\hline (Constant) & 4.649 & .587 & & 7.916 & .000 \\
\hline $\begin{array}{l}\text { total cost } \\
\text { of travel }\end{array}$ & $\begin{array}{r}2,64 \mathrm{E}- \\
03 \\
\end{array}$ & .000 & .140 & 2.162 & .033 \\
\hline distance & -.026 & .002 & -.753 & $10.849^{-}$ & .000 \\
\hline income & $\begin{array}{r}-1,97 \mathrm{E}- \\
04 \\
\end{array}$ & .000 & -.126 & -1.351 & .180 \\
\hline education & .184 & .136 & .141 & 1.356 & .178 \\
\hline age & -.014 & .012 & -.094 & -1.173 & .244 \\
\hline
\end{tabular}

a. Dependent Variable: The frequency of the number of visits

Based on the results of the calculation of travel costs with regression analysis, the regression equation with a constant value of 4.649 is as follows :

$$
\begin{aligned}
Y=4,649+2,643 E-6 X_{1}-0,26 X_{2} \\
-1,968 E-7 \\
+0,184 X_{4}-0,012 X_{5}
\end{aligned}
$$

Among the five independent variables tested $\left(\mathrm{x}_{1}\right)$ total cost of travel, $\left(\mathrm{x}_{2}\right)$ distance, $\left(\mathrm{x}_{3}\right)$ income, $\left(\mathrm{x}_{4}\right)$ education and $\left(\mathrm{x}_{5}\right)$ age, only variable $\left(\mathrm{x}_{1}\right)$ total travel cost biaya dan $\left(\mathrm{x}_{2}\right)$ distance which significantly affects the frequency of the number of visits. The influence of these two variables has a negative effect on the frequency of the number of visits. This means that the higher the travel costs incurred by visitors and the farther the distance to a tourist attraction, the less the frequency of the number of tourist visits. The results of the study are in line with what was stated $[10] ;[11]$ that tourist visits will be influenced by travel costs incurred by tourists and the distance to tourist sites as a tourist choice. Furthermore, to calculate consumer surplus, the results of the regression analysis are then entered into the integral equation as follows :

$$
C S=\int_{31.000}^{531.000} 4,649-0,000002643 X_{1}
$$

Consumer surplus is calculated based on the average value of the number of tourist visits during the covid 19 pandemic from March 2020 - March 2021. The result of the calculation is that the consumer surplus value is $\mathrm{Rp}$. 878,551,-/individual/visit.In the period from March 2020 - March 2021, during the COVID-19 pandemic with a 4-month lockdown, the number of visitors to the Gemah beach tourism object was only 26,009 people. Based on the number of visitors, the economic potential of the Gemah Beach tourist attraction as a direct use value during the covid 19 pandemic from March 2020 - March 2021 is IDR $22,850,237,669,-$. This value is relatively lower than the economic value obtained before the COVID-19 pandemic. This happened because the number of visitors in that period was only 26.009 people, while in 2019 2020 before the covid pandemic the number of visits reached 431.301 people.

The next approach used to calculate the value of economic benefits from the Gemah Beach tourism object uses an indirect use value approach. The indirect value approach is calculated using the total benefit method of the Gemah Beach tourist attraction. The calculation of the total benefit method is based on the average annual profit of the parties who indirectly feel the economic benefits of the Gemah Beach tourist attraction. The economic activity actors are calculated because they get economic benefits from the existence of Gemah beach tourism objects, namely traders, employees/managers, parking revenues and retribution. Based on the average value of the profits obtained from the perpetrators of these economic activities at the Gemah Beach tourist attraction during the covid-19 pandemic from March 2020 - March 2021, an economic value of IDR 4,809,397,500 was obtained. The percentage of the economic value of economic activity actors in the Gemah Beach tourism object can be seen in Figure 3 below.

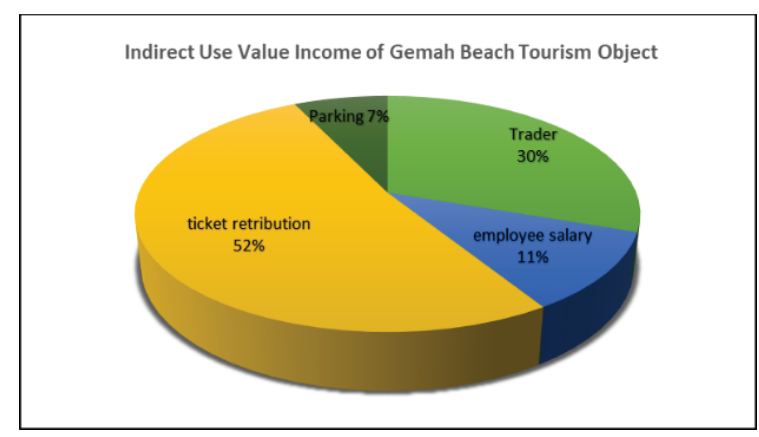

Fig. 3. Percentage of Indirect Use Value Contribution

Based on the figure 3, the income from the entrance fee has the greatest economic value benefit compared to income in other fields with a percentage of $51.75 \%$, while the second-largest income is economic income from traders who trade in the Gemah Beach tourist area with a percentage of $30.27 \%$ of the total indirect economic value. Meanwhile, for other parties, only $10.83 \%$, i.e. employee salaries, and parking revenues, only $7.15 \%$ of the total value of the indirect economic value of the Gemah Beach tourist attraction during the covid-19 pandemic. The contribution of economic value from the ticket retribution means that during the COVID-19 pandemic, visitors who came to Gemah Beach did not spend a lot of money, especially related to buying food. This is in line with what was stated by [12] ; [13] ; [14] The income of the UMKM sector, including the culinary sector, during the COVID-19 pandemic, experienced a decline in turnover because buyers were afraid. Therefore, to increase sales 
turnover, there must be a special strategy so that consumers feel comfortable and safe shopping or consuming the food they buy.

To calculate the economic benefits of the use value of the choice of Gemah Beach tourism object, the contingent valuation method (CVM) is used. The option use value is calculated based on the willingness to pay (WTP) of tourists for services provided by natural resources and the environment in order to maintain their sustainability [15]. The results showed that the willingness to pay of tourists for the sustainability of the Gemah Beach tourism object was an average of IDR 6,120 / tourist. Based on this, if the number of visitors is 26,0009 people during the period March 2020-March 2021 , the use value of the choice of the Gemah Beach tourist attraction is Rp. 159,172,020,-. This phenomenon means that Gemah Beach tourists have a concern for the sustainability of the existence of tourism objects. This is in line with what was stated by [16] that tourists have a concern for the preservation of the tourism environment as a form to maintain the beauty and sustainability of the tourism object. However, the role of managers and stakeholders in maintaining the environmental sustainability of a tourist area is also very important.

Meanwhile, the value of economic benefits of the bequest value of the Gemah Beach tourism object, the willing to pay (WTP) method is used. The bequets value is calculated from the amount of costs used to maintain the magnificence and cleanliness of the Gemah Beach area given by tourists, with the aim that tourism objects can be enjoyed by future generations. The results of the study obtained the value of bequest with an average WTP of Rp. 5,920/tourist. If the average WTP value is IDR 5,920 and the number of tourist visits during the COVID-19 pandemic is 26,009 people, then the bequest value for the preservation and cleanliness of the Gemah Beach tourist attraction is IDR 153,970,320. This phenomenon also provides an image that tourists have a sense of caring for the magnificence and cleanliness of the Gemah Beach area. This is in line with what was stated by [17] that currently tourists are starting to have a high awareness of the cleanliness and magnificence of the tourist area. This can be seen from the results of research in Bukit Matang Kaladan Banjar, where the average WTP value given by tourists is Rp. 11,260 /tourist. Thus, it can be said that tourists in general already have a high enough concern for the cleanliness and beauty of the current tourist area and to be enjoyed by future generations.

Meanwhile, to see the total economic value (TEV) of various economic values during the COVID-19 pandemic, all the use values obtained from the Gemah Beach tourism object are added up in value. In more detail, the total economic value of Gemah Beach tourism object can be seen in Table 2 below.
Table 3. Total Enomic Value

\begin{tabular}{|l|rr|c|}
\hline $\begin{array}{c}\text { Use Value } \\
\text { Type }\end{array}$ & \multicolumn{2}{|c|}{ Total/Rupiah } & $\begin{array}{c}\text { Percentage } \\
\text { (\%) }\end{array}$ \\
\hline $\begin{array}{l}\text { Direct Use } \\
\text { Value } \\
\text { (DUV) }\end{array}$ & $\mathrm{Rp}$ & 22.850 .237 .669 & 81,22 \\
\hline $\begin{array}{l}\text { Indirect } \\
\text { Use Value } \\
\text { (IUV) }\end{array}$ & $\mathrm{Rp}$ & 4.809 .397 .500 & 17,09 \\
\hline $\begin{array}{l}\text { Option Use } \\
\text { Value (OV) }\end{array}$ & $\mathrm{Rp}$ & 159.172 .020 & 0,57 \\
\hline $\begin{array}{l}\text { Existence } \\
\text { Value (XV) }\end{array}$ & $\mathrm{Rp}$ & 159.172 .020 & 0,57 \\
\hline $\begin{array}{l}\text { Bequest } \\
\text { Value (BV) }\end{array}$ & $\mathrm{Rp}$ & 153.970 .320 & 0,55 \\
\hline $\begin{array}{l}\text { Total } \\
\text { Enomic } \\
\text { Value } \\
\text { (TEV) }\end{array}$ & $\mathrm{Rp}$ & 28.131 .949 .529 & 100 \\
\hline
\end{tabular}

Source: Data Processing Results, 2021

The calculation results in Table 1 show that the total economic value (TEV) of the Gemah Beach tourist attraction during the Covid-19 pandemic from March 2020-March 2021 is IDR 28,131,949,529. The contribution of each value to the total value varies; the direct use value contributed the most, which was $81.22 \%$ of the total economic value, then the indirect use value contributed $17.09 \%$ of the total economic value. Meanwhile, the other value, i.e. the option use-value, the existence value, and the bequest value, contributed less than $1 \%$ and ranged from $0.5 \%$ of the total economic value of the Gemah Beach tourism object. The results of these calculations provide an image that the COVID-19 pandemic has affected the total economic value (TEV) of Gemah Beach tourism due to a decrease in the number of visitors. Thus, it is quite logical that the number of visitors will affect the direct use value and indirect use value of the Gemah Beach tourism object.

The economic value generated by Gemah Beach tourism during the covid-19 pandemic can then be used as a reference in developing tourist objects in the face of the covid-19 pandemic. The strategy that can be done in dealing with the pandemic is to optimize economic potential by completing facilities and infrastructure in accordance with the Covid-19 health protocol and continue to urge tourists and managers to continue to comply with health protocols while traveling at the Gemah Beach tourist attraction in order to reduce the spread of the virus. the virus and the tourism industry continues to operate as before.

\section{Conclusion}

During the COVID-19 pandemic from March 2020March 2021, the types of economic activities at Gemah Beach tourism objects are still quite diverse, even though there are social restrictions and lockdown policies for 4 months. Meanwhile, the results of the 
economic valuation obtained the total economic value (TEV) of the Gemah Beach tourism object during the COVID-19 pandemic from March 2020-March 2021, a total economic value of IDR 28,131,949,529 was obtained. The largest contribution to the total economic value (TEV) is provided by direct use value, which is $81.22 \%$ and indirect use value, which is $17.09 \%$, while option use value, existence value and inheritance value only contribute less than $1 \%$. Optimizing the economic and natural potential of the Gemah Beach tourist attraction by fulfilling facilities and infrastructure that are in accordance with the COVID-19 health protocol can be used as a strategy in dealing with the COVID-19 pandemic so that the tourism industry can continue to run and the spread of the virus can be controlled.

\section{Acknowledgement}

On this occasion the authors would like to thank the UGM Publisher and Publication Board (PBB) for providing RTA 2021 Grant funds, so that the authors can attend the ICST 2021 seminar and complete the thesis.

\section{References}

[1] W. Fan et al., "Holmes Edward C., Zhang Yong-Zhen. A new coronavirus associated with human respiratory disease in China," Nature, vol. 579, no. 7798, pp. 265-269, 2020.

[2] H. Zhang, T. Cho, and H. Wang, "The Impact of a Terminal High Altitude Area Defense Incident on Tourism Risk Perception and Attitude Change of Chinese Tourists Traveling to South Korea," Sustainability, vol. 12, no. 1, p. 7, 2020.

[3] M. Sigala, "Tourism and COVID-19: Impacts and implications for advancing and resetting industry and research," J. Bus. Res., vol. 117, no. June, pp. 312-321, 2020, doi: 10.1016/j.jbusres.2020.06.015.

[4] G. Garrod and K. G. Willis, "Economic valuation of the environment," Books, 1999.

[5] E. B. Barbier, M. Acreman, and D. Knowler, "Economic valuation of wetlands: a guide for policy makers and planners," 1997.

[6] S. Zandi, S. M. Limaei, and N. Amiri, "An economic evaluation of a forest park using the individual travel cost method (a case study of Ghaleh Rudkhan forest park in northern Iran)," Environ. Socio-Economic Stud., vol. 6, no. 2, pp. 48-55, 2018, doi: 10.2478/environ-20180014.

[7] M. Suparmoko, D. Sudirman, Y. Setyarko, and H. S. Wibowo, "Valuasi Ekonomi Sumberdaya Alam dan Lingkungan(Cetakan Pe)," Yogyakarta: BPFE-Yogyakarta, 2014.

[8] A. Fauzi, "Valuasi ekonomi dan penilaian kerusakan sumber daya alam dan lingkungan," IPB Pr, Bogor, 2014.

[9] W. Sumatera, T. Kusumastanto, and A. Fahrudin, "Penilaian Ekonomi Wisata Pesisir
Kawasan Carocok Painan, Kabupaten Pesisir Selatan, Sumatera Barat Economic Assesment of Coastal Tourism in Carocok Painan, Pesisir Selatan Pendahuluan Tinjauan Literatur," vol. 18, no. 1, pp. 1-21, 2018.

[10] S. Indayani and B. Hartono, "Analisis Pengangguran dan Pertumbuhan Ekonomi sebagai Akibat Pandemi Covid-19," J. Perspekt., 2020.

[11] F. Zulpikar, P. D. E., T. V. Shelvatis, K. K. Komara, and M. Pramudawardhani, "Valuasi Ekonomi Objek Wisata Berbasis Jasa Lingkungan Menggunakan Metode Biaya Perjalanan di Pantai Batu Karas Kabupaten Pangandaran," J. Reg. Rural Dev. Plan., vol. 1, no. $1, \quad$ p. 53, 2017, doi: 10.29244/jp2wd.2017.1.1.53-63.

[12] L. D. Septiningrum, "Manajemen Strategi Untuk Meningkatkan Penjualan Food And Beverage Di Era Pandemi Covid 19," JMBI UNSRAT (Jurnal Ilm. Manaj. Bisnis dan Inov. Univ. Sam Ratulangi)., vol. 8, no. 1, 2021.

[13] W. laura Hardilawati, "Strategi Bertahan UMKM di Tengah Pandemi Covid-19," J. Akunt. dan Ekon., vol. 10, no. 1, pp. 89-98, 2020, doi: 10.37859/jae.v10i1.1934.

[14] I. Fitriyani, N. Sudiyarti, and M. N. Fietroh, "Strategi Manajemen Bisnis Pasca Pandemi Covid-19," Indones. J. Soc. Sci. Humanit, vol. 1, no. 2, pp. 87-95, 2020.

[15] A. Bharali and R. Mazumder, "Application of travel cost method to assess the pricing policy of public parks: the case of Kaziranga National Park," J. Reg. Dev. Plan., vol. 1, no. 1, pp. 4452, 2012.

[16] G. J. Ghobadi and M. S. Verdian, "The environmental effects of tourism development in Noushahr," Open J. Ecol., vol. 6, no. 9, pp. 529-536, 2016.

[17] M. R. Fikri and N. Rahmini, "Analisis Willingness To Pay Pada Wisata Bukit Matang Kaladan Desa Tiwingan Lama Kecamatan Aranio Kabupaten Banjar Kalimantan Selatan," JIEP J. Ilmu Ekon. dan Pembang., vol. 3, no. 1, pp. 158-170, 2020. 